\title{
CHANGES IN SOCIOCULTURAL REPRESENTATIONS IN POPULAR DIGITAL GAMES
}

\author{
İdris GÖKSU \\ Ataturk University, Computer Education \& Instructional Technology, PhD Student \\ idrisgoksu47@hotmail.com.tr \\ Alper ASLAN \\ Ataturk University, Computer Education \& Instructional Technology, PhD Student \\ alperaslan@gmail.com \\ Türkan KARAKUŞ \\ Ataturk University, Computer Education \& Instructional Technology, Assistant Professor \\ turkan.karakus@gmail.com
}

\begin{abstract}
The aim of this study is to investigate digital games with respect to sociocultural aspects and examine whether they are influenced by social and cultural events. In total, 14 digital games were studied by the researchers through documentation analysis. Results showed that sociocultural factors and current events were heavily featured in games from 2002-2004, while 2012-2014 games highlighted social interaction, natural environments of the world, and exceptional, action-packed events. This study is valuable for revealing how games reflect sociocultural changes over time.
\end{abstract}

Keywords: Digital games, socio-cultural issues, content analysis, game scenario, popular games

\section{POPÜLER DİJITAL OYUNLARDA SOSYOKÜLTÜREL DEĞİŞIMLER}

\section{ÖZ}

$\mathrm{Bu}$ araştırmanın amacı, dijital oyunları sosyokültürel açıdan inceleyip sosyal ve kültürel olayların oyunlara bir yansımasının olup olmadığını irdelemektir. Toplam 14 dijital oyun araştırma kapsamına dâhil edilmiş ve doküman analizi temel alınarak oyunlar araştırmacılar tarafindan irdelenmiştir. Elde edilen sonuçlar, 2002-2004 yılı dijital oyunlarında genellikle tarihsel unsurların yer aldığı ve tarihsel olayların; 2012-2014 yılı dijital oyunlarında ise daha çok sosyal hayat, dünyanın doğal ortamı ve gelecekte meydana gelebilecek aksiyon içerikli olayların konu edinildiğini göstermiştir. Bu araştırma, oyunlarda zamanla meydana gelen değişimin ortaya çıkarılması açısından önemlidir.

Anahtar Kelimeler: Dijital oyunlar, sosyokültürel unsurlar, içerik analizi, oyun senaryosu, popüler oyunlar 


\section{INTRODUCTION}

In recent years, the number of people using portable devices such as tablets, smart phones, and laptops has increased considerably, and with such easy access to the Internet, many people spend most of their free time online. Digital games have gained importance as a result of using these devices, and designers have started to develop games in line with rising generations. These digital games have strategic scenarios with realistic graphics and narratives. Individuals tend to do things they cannot do in real life through these games, and they can become addicted to them in a short time (Sucu, 2012). Due to these developments, social games have started to lose popularity (Grifitts, 2010).

People mostly play digital games in their free time in order to relax and enjoy attractive game designs (Author removed). Boyle, Connolly, and Hainey (2011) determined through a content analysis that playing computer games usually has perceptive, cognitive, affective, and motivational effects. Huizinga (1995) observed that games have always been a part of culture and hold an important place in terms of cultural function. In this respect, as digital games replace social games, the transfer of culture should be investigated. Particularly, these games are becoming more similar to real life and rely intensely on representing cultural factors accurately. As far as socio-cultural factors are concerned, some individuals over-identify with games, withdrawing from real life (Bat1, 2011). This situation decreases social relationships among people; on the other hand, it increases social communication (Sucu, 2012). The increase in social communication provides an atmosphere where players participate in intercultural exchange by using social and political expressions (Binark \& Bayraktutan-Sütcü, 2009).

It is possible to encounter ideological factors in digital games designed within a particular sociocultural structure (Kan, 2012). Demir (2005) has defined an ideology as a set of social, political, moral, and religious activities that an individual performs. Meanwhile, Mardin (2007) explains it as a map directing the people. Güriz (1995) defined ideology as "a system of ideas which includes social, political and economic demands that direct the human behaviors and are based on religion factors" (3). In some digital games, convincing techniques are used to relay political messages (Malliet, Thysen, and Poels, 2011). These techniques can also be considered ideological factors. Sisler (2005) has indicated that games represent an ideological world and has claimed that political cases are intentionally conveyed to the target populace in this way. Political factors here are defined as the fair organization of the common benefits of individuals in a society and directed towards that society's sustainability (Oktay, 2009). Galloway (2004) has also pointed out how social situations in digital games represent present-day political situations in a suitable and realistic way, emphasizing political factors.

Another factor present in digital games is the social element. Digital games are a part of culture, and being social is often their main focus (Sisler, 2005; Squire, 2006). Players may encounter examples of real life, whether political, economic, cultural, or social (Galloway, 2004; Squire, 2006). Squire and Jenkins (2003) revealed in their study that the game Civilization III includes factors that reflect the impact of 6000 years of technological development and presents developments in science, religion, and art all together. Historical factors are defined as factors that make a factual statement about the activities of people living in the past by depicting their place and time (Şimşek, 2011).

In addition to historical factors, many games have a scenario rooted in historical but fictionalized content (Dondlinger, 2007). Brisbois (2007) has indicated that game designers need to tell a story, just as in films and TV programs, to sustain their existence. Digital games are often influenced by scenarios in television, films, and cartoons (Rutter \& Bryce, 2006), and these scenarios may cause game players to feel nervous, scared, sad, excited, or happy (Sayllgan, 2012). Warnes (2005) has pointed to the games Baldur's Gate I and II to show the importance of scenario and story in games. The literature reveals how ideological, political, social, and historical factors are similar and in some situations intertwined, as well as how they are defined differently across time. 
Clearly, there are many factors in digital games. An analysis of the most popular modern digital games and their equivalents from a decade ago is important in terms of identifying the development of and factors in the games as well as whether they are affected by social events. It will also be valuable to know whether the increase of people playing these games, along with the decrease in social games, has conveyed more culture into them, particularly with regard to certain factors (see Fig. 1).

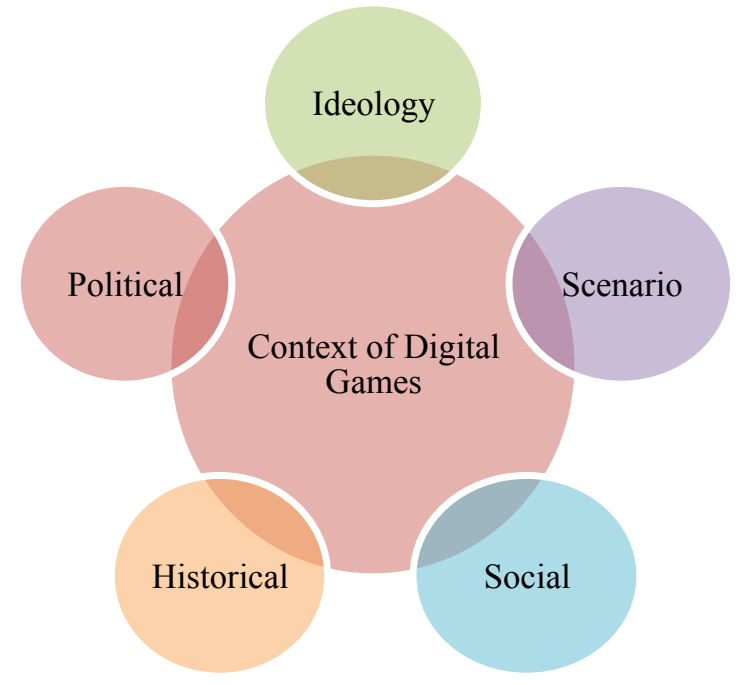

Fig. 1. Factors analyzed in the games

This study presents a socio-cultural analysis of changes in popular digital games from today and a decade ago, asking five research questions:

- Which ideological factors are covered?

- What kind of political incidents are included?

- Which historical factors are used?

- Which social factors are mentioned?

- How close is the scenario to real life?

\section{METHOD}

This study is a document analysis of the most popular digital games of 2002-2004 and 2012-2014 in terms of ideological, political, historical, social factors and scenarios. The approach of document analysis, which is assessed within qualitative study, refers to the media that contains the facts to be studied (Yıldırım \& Şimşek, 2011). This method is used to analyze materials depending on the aim of the study and to determine the data to be obtained (Çepni, 2007). In addition to documents, photographs, film, and sound (Yıldırım \& Şimşek, 2011), the materials assessed may also be digital games. The best way to analyze a game is to play the game as a player (Elverdam \& Aarseth, 2007). The aim of using this method is allowed the researchers to determine the above-mentioned factors by analyzing the games and find out the changes first hand. After analyzing game magazines, forums, and YouTube, the most popular 14 digital games of 2002-2004 $(n=6)$ and 2012-2014 $(n=8)$ were identified. Table 1 lists these games by name, country, company, Entertainment Software Rating Board (ESRB) rating, and content descriptors. 


\begin{tabular}{|c|c|c|c|c|c|}
\hline & Name of the Game & Country & Company & ESRB & Content Descriptor \\
\hline \multirow{6}{*}{ 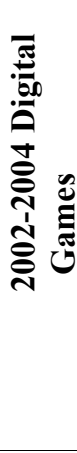 } & Call of Duty (COD) & USA & Activision & $\mathrm{T} 13+$ & Blood, Violence \\
\hline & Counter Strike (CS) & USA & Valve & M 17+ & Blood, Intense Violence \\
\hline & FIFA & USA & Electronic Arts & E $6+$ & \\
\hline & $\begin{array}{l}\text { Grand Theft Auto: } \\
\text { Vice City (GTA) }\end{array}$ & SCOTLAND & Rockstar Games & M 17+ & $\begin{array}{l}\text { Blood and Injury, Slang, High } \\
\text { Sexual Content, and Violence }\end{array}$ \\
\hline & $\begin{array}{l}\text { Medal of Honor: } \\
\text { Pacific Assault (MOH) }\end{array}$ & USA & Electronic Arts & T $13+$ & Blood, Slang, Violence \\
\hline & $\begin{array}{l}\text { Need For Speed Underground } \\
\text { (NFS) }\end{array}$ & USA & Electronic Arts & E $6+$ & $\begin{array}{l}\text { Light Slang, Thought- } \\
\text { Provoking Themes }\end{array}$ \\
\hline \multirow{8}{*}{ 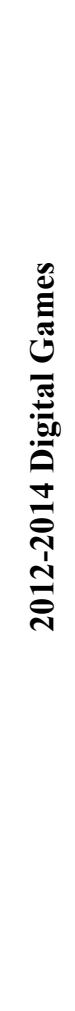 } & $\begin{array}{l}\text { Aliens: Colonial } \\
\text { Marines } \\
(\mathrm{ACM})\end{array}$ & JAPAN & Sega & M 17+ & $\begin{array}{l}\text { Blood and Injury, Intense } \\
\text { Violence, Slang }\end{array}$ \\
\hline & $\begin{array}{l}\text { League of Legends-Online } \\
\text { (LOL) }\end{array}$ & USA & Riot Games & T $13+$ & $\begin{array}{l}\text { Blood, Fantasy Violence, } \\
\text { Light Thought-Provoking } \\
\text { Themes, Use of Tobacco and } \\
\text { Alcohol }\end{array}$ \\
\hline & Crysis 3 & USA & Electronic Arts & M 17+ & Blood, Slang, Violence \\
\hline & $\begin{array}{l}\text { Call of Duty: Ghost } \\
\text { (CODG) }\end{array}$ & USA & $\begin{array}{l}\text { Activision/ } \\
\text { Blizzard }\end{array}$ & M 17+ & $\begin{array}{l}\text { Blood, Drug Use, Intensive } \\
\text { Violence, Slang }\end{array}$ \\
\hline & Grant Theft Auto V (GTA-V) & SCOTLAND & Rockstar Games & M 17+ & $\begin{array}{l}\text { Blood and Injury, Intense } \\
\text { Violence, Mature Humor, } \\
\text { Nakedness, Slang, High } \\
\text { Sexual Content, Use of } \\
\text { Tobacco and Alcohol }\end{array}$ \\
\hline & Dead Island (DI) & AUSTRIA & Koch Media & M 17+ & $\begin{array}{l}\text { Blood and Injury, Intense } \\
\text { Violence, Slang, Drug Use }\end{array}$ \\
\hline & Metro Last Light (MLL) & AUSTRIA & Koch Media & M 17+ & $\begin{array}{l}\text { Blood, Intense Violence, } \\
\text { Nakedness, Slang, Sexual } \\
\text { Content, Use of Drug and } \\
\text { Alcohol }\end{array}$ \\
\hline & Tomb Raider (TR) & JAPAN & Square Enix, Inc & M 17+ & $\begin{array}{l}\text { Blood and Injury, Intense } \\
\text { Violence, Slang }\end{array}$ \\
\hline
\end{tabular}

Table 1: List of Analyzed Games and Their Properties

In this study, purposeful sampling method was applied. As games were selected, their introductory videos were watched on the Internet. Games were particularly considered for the study that featured a scenario, could be played by choosing an avatar, had an environment inspired by world culture and events, and could be easily acquired by the researchers.

\section{Data collection and analysis}

The data about the games included in the study were primarily obtained from the researchers playing the games themselves while considering the research questions. The data obtained in the course of the observations were shared by the researchers, and upon reaching common conclusions, they were organized by game. The most popular digital games of 2002-2004 and 2012-2014 were analyzed in terms of ideological, political, historical, and social factors and scenarios, and the obtained data were analyzed via descriptive analysis. The findings were interpreted, and changes and developments in the games with regard to the factors were determined. 


\section{FINDINGS \\ Digital Games from 2002-2004}

Call of Duty. This game features many countries during the course of World War II, mainly France, Germany, and Russia. The main character undergoes military training before journeying to different countries on missions. In the first part of the game, the soldier writes a letter about what he has done and what he will do next. Elements such as a radio, payphone, checkers game, wine bottles, and siren sounds during fighting reflect the time period. A large cross on a gravestone, a swastika, and a female figure in the German military also draw attention in the game. If soldiers abandon their posts, they are shot by their commanders, and animals also perish during the game. In some scenes, German soldiers speak German, but Russian soldiers speak English. At the end of each part of the game, statements are often displayed remarking on the terrors of war: "History will be kind to me for I intend to write it!" (Churchill), "So long as there are men, there will be wars" (Einstein), "Only the dead have seen the end of war" (Plato), "A single death is a tragedy; a million deaths is a statistic" (Stalin).

Grand Theft Auto. The theme of this game, generally reflecting American culture, focuses on several main characters who carry out missions in order to advance in the world of crime. The game takes place in the USA in the 1980s and heavily promotes disloyalty, bribery, and corruption. Specifically, it was designed to resemble Miami, Florida, in 1986. The game is full of slang, swear words, and scornful statements. Furthermore, car thefts, nakedness, the drug trade, and spying are also rampant.

Medal of Honor. The game, which was inspired by the film Saving Private Ryan, takes place during the 1940s and World War II in the Pacific Front. An American marine infantry is the main character, and gameplay begins with military training. Soldiers mention their interest in magazines, promote helpfulness, build shelter, transfer the wounded to medical facilities, and obey the orders of their commanders. Some missions include fighting against Japanese soldiers. When the missions are completed, the soldiers are rewarded with a rank or a medal.

Need for Speed: Underground. In this race and speed-based game, instances of stopping people's cars and stealing them are not punished. Also, it is important to avoid getting the car stuck against a wall or other vehicle, to skid the car, and to pass very close to other cars. One of the most conspicuous aspects of the game is the eye-catching placement of advertisements on the floors. The normal drivers are unarmed and defenseless. When they are waylaid on the road, they stay still and neither call the police nor call out for help. This situation may lead to aggressiveness in game players.

FIFA Football 2003. The interest in football is clearly seen from the full audience in the platforms around the pitch. Even in defeat, the footballers from each team congratulate each other, though they rarely apologize after fouls. In fact, the referee allows for some harsh fouls and actions, often showing yellow cards instead of red. The cheering from the platforms increases when there is a foul. The footballers react emotionally when the ball does not move the way they want. In particular, some famous footballers' behaviors are imitated in the game. The abilities of the footballers are accurately drawn from real life.

Counter Strike. This game incorporates a specific and popular historical map called Dust. The game is based on a clash between two groups, the terrorists and the anti-terrorists. The uniforms and arms of the terrorist group show verisimilitude for the time. This game can be played on a local area network, and it is important to act as a group to succeed.

\section{Digital Games from 2012-2014}

Aliens: Colonial Marines. The missions in the game are carried out by the player, who fights against alien creatures. The avatar undergoes a medical check and is motivated to fight. Quick responses and attention skills play a significant role in gameplay. Besides fear being an effective factor, acting as a group and team helpfulness also merit attention. A device with a radar indicator and the ability to see friends and nearby creatures gives confidence to the character and encourages him. Many technological devices (automatic or encoded doors, cameras, monitors, guns) also attract attention. The creatures in the game are easily killed. 
League of Legends. The game avatar, or the champion, is inspired by mythological heroes. This character has different skills, and with the support of magic a fight starts between two teams. The game encourages taking responsibility, building friendships, being honest, cooperating, being modest in victory and virtuous in defeat, and being a role model by guiding inexperienced players. Certain beasts, such as a wolf or dragon roam the forest without attacking, and the game encourages killing them. The chosen champion returns to life shortly after being killed. The game begins with the significant quote, "The ones that want to kill me are innumerable. They are in search of justice. As for me, I have already forgotten the meaning of this word, and now my only friend is the wind blowing nearby." During the game, several statements are heard frequently: "Do not deviate from the aim," "Peace requires determination," "We are stronger together," "Always think big," "Do not confuse weakness with mercy," and "One heart, one nation."

Crysis 3. In this game, New York has been transformed into a forest by a company called CELL, who is developing technology to conquer the earth. The main character, Prophet, is trying to stop them. Prophet faces soldiers, helicopters, and security systems with automatic weapons, creatures, mines, and more. Cutting edge technology is used in the game, including encoded entrances, encrypted codes, and armored uniforms with invisibility features, thermal cameras, and virtual reality options. The Prophet character undertakes a savior mission, embodying the meaning of the name itself. It is stressed in the game that technology is the greatest weapon of all. The technological weapons and the reality of the environment are shown in Figure 2.

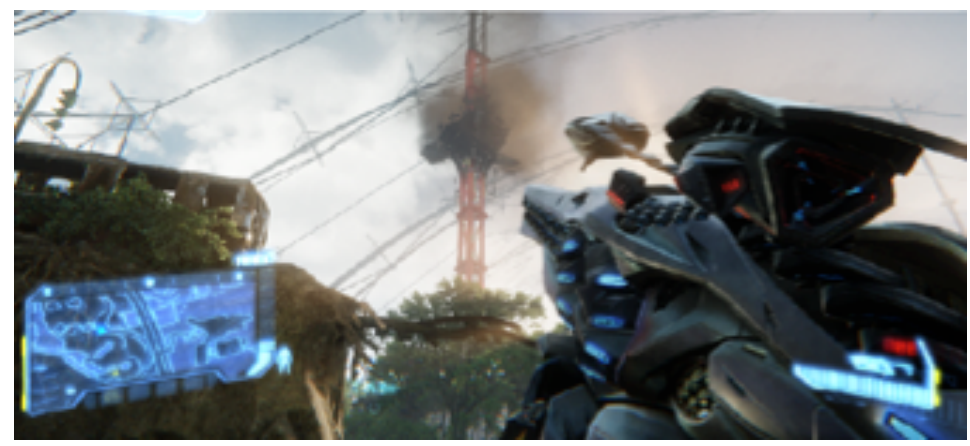

Figure 2: The technology used (Crysis3)

Call of Duty: Ghosts. A federation trying to prevent global economic crisis and become a new superpower takes control of the spacecraft ODIN, which carries a super weapon. The Federation devastates most U.S. cities, and the American astronaut survivors intervene to save the world from total destruction. In the year 2023, Logan, the main character, and his brother Hesh join the Ghosts, a group of Special Forces personnel working together against the Federation. It is forbidden to kill civilians in this game. In the beginning, young people are shown taking pictures of the American bombardments. Moreover, a trained dog named Riley with some technological equipment plays an important role in carrying out the missions in the game (Figure 3).

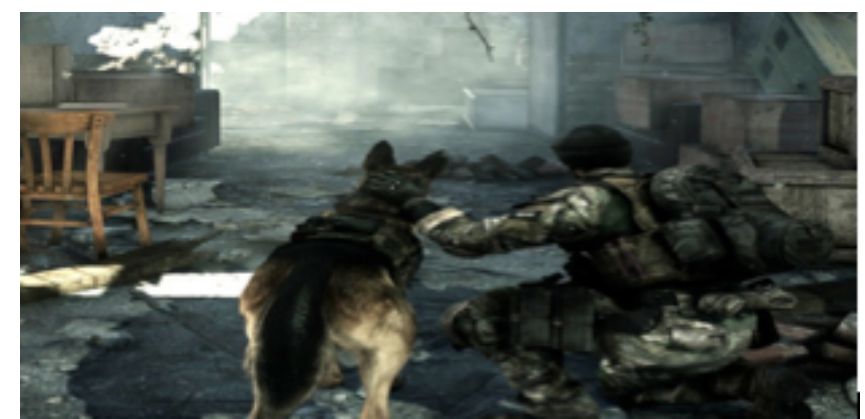

Figure 3: The Dog Riley (Call of Duty-Ghost)

Logan is able to protect his dog from wolves even when he is wounded, an indicator of his team solidarity and devotion. In one mission, the armed Federation soldiers play football. When Logan dies, 
the warning "You have left your friends alone" appears on the screen. Infecting Federation computers with viruses, passing between buildings on ropes, and gaining building access while hanging from a rope off the top of a high building are examples of scenes full of action that also mimic potential real life situations. Using a device to scan objects and people from a distance, detecting faces and revealing personal details, is also encountered in the game.

Dead Island. This game resembles a horror movie: survivors attempt to escape an island overrun by other vacationers, who have transformed into zombies. There is no linear scenario, and loneliness and fear are primary themes. One character has to kill his family after discovering they are zombies. The game reflects real life by indicating decreased durability of tools (e.g., iron bars, canoe oars, pieces of wood) and increased tiredness with activity. The screams and desperation of the survivors frequently draw the attention of zombies. Players primarily conduct mini missions in which they respond to requests for help, or in one case, organize a funeral after killing a relative.

Grand Theft Auto $V$. This game offers the well-designed world of central characters Michael, Franklin, and Trevor. Another main character is a Rottweiler owned by another character. Although this dog is not trained, it frequently helps on missions and appears at unexpected times. The game progresses through professional robbery missions, as the player builds a strategic plan according to the characteristics and skills of the main characters. Details of a mission may include photographing a location, acquiring tools, giving bribes, hiring hackers or bomb experts, and selecting a getaway driver. The game incorporates artificial intelligence to simulate real life. The game also includes social events such as water sports, parachute jumping, car races, crime fighting, going to the club, hanging out with friends, surfing the Internet, watching TV, and getting tattoos.

Metro: Last Light. This game reflects the life of survivors who take shelter in a metro after a nuclear disaster in Moscow. The people cannot leave because of a radioactive storm and are attacked by mutants. Colonel Miller, the leader of a sniper team, tries to kill a Native American child who has survived. Artyom, a member of the sniper team, thinks that his life depends on this child and tries to get in contact with him. The survivors try to lead a normal life by playing checkers, listening to music, and playing guitar; the people also use bullets as currency. As in the image of Figure 4, it is possible to see that a child has to survive as a result of nuclear storm and he tries to lead his own life.

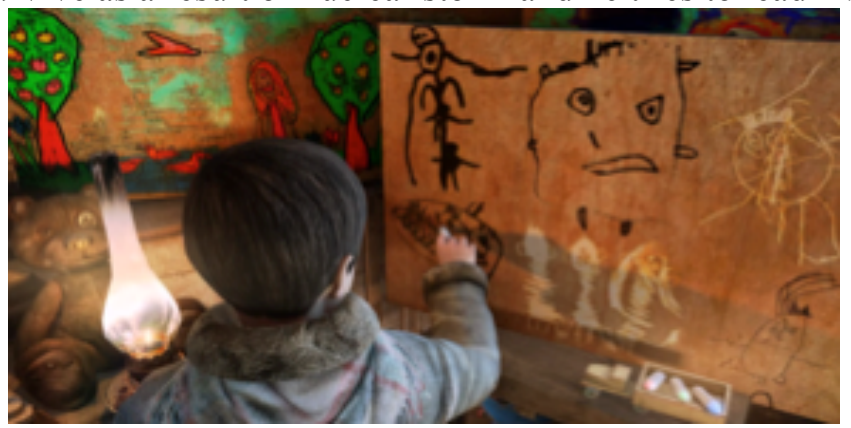

Figure 4: The child in the game Metro Last Light

Tomb Raider. The first thing that draws attention in the game is the natural environment, in which it is possible to hear crows cawing, wolves howling, and water dripping. Lara, the central character, is a well-designed female adventurer in search of ancient relics who is caught in a storm on an island, and the game scenario centers on her struggle with other powers there. Lara finds herself alone in a horrible place. Because of being hungry, she disregards her love for animals and kills a deer. Her feelings of hunger, grief, loneliness, coldness, crying, and fear are often expressed. While Lara starts with an arrow and bow, she finishes with developed weapons. Her character, which begins being timid and true-hearted, changes significantly by the end of the game. She often reaches her target by climbing using special skills. The richness of Japanese culture and history is acutely handled, and graves and temples where people are sacrificed in the name of God are also a focus. 
Once the 14 digital games were analyzed and described in detail, their ideological and political factors and scenarios were studied; findings are presented below.

\section{Ideological Factors in Digital Games}

As Table 2 shows, ideological factors appear frequently in modern games. In the games produced between 2002 and 2004, the power of the USA, its culture, and its advertising were at the forefront, and while the German language was given importance, the Russian language was in the background. Also, the use of the swastika can be considered propaganda. Incentives for bribery, repossession, and corruption were also handled in the games, as well as the importance of money and gold. The games of 2002-2004 presented no religious factors apart from a cross, unlike the games of 2012-2014. The intentional use of the term Prophet, reincarnation, not being scared of death, symbols belonging to Buddhism, and religious funerals were also covered in these games. Further, American citizens often took on the role of saving the world, and disasters like nuclear storms can be considered another kind of propaganda.

\begin{tabular}{|c|c|c|}
\hline Ideological Factors & 2002-2004 & 2012-2014 \\
\hline Economic System & $\begin{array}{l}\text { Incentives for bribery and corruption } \\
\text { (GTA) }\end{array}$ & $\begin{array}{l}\text { Importance of gold (LOL) } \\
\text { Incentives for bribery and corruption (GTA) } \\
\text { Incentives for repossession (GTA) }\end{array}$ \\
\hline Propaganda & $\begin{array}{l}\text { Company advertisement (NFS) } \\
\text { Importance of German language } \\
\text { (COD) } \\
\text { Power of the USA (MOH) } \\
\text { Praise of American culture (GTA) } \\
\text { Russian language at the background } \\
\text { (COD) } \\
\text { Swastika symbol (COD) }\end{array}$ & $\begin{array}{l}\text { Damages of nuclear power (MLL) } \\
\text { The reality of aliens (Crysis } 3 \text { ) } \\
\text { The USA saving the world from secret } \\
\text { organizations (CODG) }\end{array}$ \\
\hline Religious Factors & The cross (COD) & $\begin{array}{l}\text { Buddhism (TR) } \\
\text { Fear of death and reincarnation (LOL) } \\
\text { Religious funeral (DI) } \\
\text { The term "Prophet" (Crysis 3) }\end{array}$ \\
\hline
\end{tabular}

Table 2: Ideological Factors in the Games

\section{Political Factors in Digital Games}

Table 3 shows political factors from the games of 2002-2004, such as the emergence of terrorism, emphasis on the effects of war, and the necessity of rewarding soldiers. The importance of military discipline and obeying orders was stressed, ensuring a lawful and regulated environment, though violating traffic rules was also often encouraged. In FIFA, the perception of being against violence in football was presented, while starting and managing a gang was encouraged in GTA.

\begin{tabular}{lll}
\hline Political Factors & $\mathbf{2 0 0 2 - 2 0 0 4}$ & $\mathbf{2 0 1 2 - 2 0 1 4}$ \\
\hline Illegal Organization & Starting a gang and managing it (GTA) & $\begin{array}{l}\text { Creating a secret gang (CODG) } \\
\text { Starting a gang and managing it (GTA) }\end{array}$ \\
\hline Law and Order & $\begin{array}{l}\text { Being against violence in football (FIFA) } \\
\text { Obeying orders (MOH) }\end{array}$ & $\begin{array}{l}\text { Providing the justice through power and } \\
\text { magic (LOL) }\end{array}$ \\
& $\begin{array}{l}\text { The importance of military discipline and } \\
\text { training (MOH, COD) }\end{array}$ & $\begin{array}{l}\text { Solving problems using violence (GTA) } \\
\text { The importance of determination for } \\
\text { peace (LOL) }\end{array}$ \\
& Violating traffic rules (GTA, NFS) & perserved \\
\hline Political Aspect & Rewarding soldiers with military rank (MOH) None observed \\
& The concept of terrorism (CS) & \\
\hline
\end{tabular}


The effects of wars (COD)

Table 3: Political Factors in the Games

No observed factors reflected political aspects in the analyzed games of 2012-2014. However, illegal activities such as starting and managing a secret gang appeared, and power and magic were emphasized as acceptable in the name of justice. The games tried to impose the perception that violence solves problems by disobeying regulations and law, though the importance of peace was also stressed.

\section{Historical Factors in Digital Games}

In the games of 2002-2004, historical factors included the Second World War, and historical architecture was at the forefront (see Table 4). The reality of animal death in war was also emphasized. In addition, Stalin was featured in Call of Duty, and the use of radios, pay phones, and weapons of the 1940s established the time period. No historical factors other than mythological heroes and Japanese architecture appeared in the studied games of 2012-2014.

\begin{tabular}{lll}
\hline Historical Factors & $\mathbf{2 0 0 2 - 2 0 0 4}$ & $\mathbf{2 0 1 2 - 2 0 1 4}$ \\
\hline Historical Architecture & General historical architecture (CS) & Japanese historical architecture (TR) \\
\hline $\begin{array}{l}\text { Historical Events and } \\
\text { Wars }\end{array}$ & $\begin{array}{l}\text { The harms of wars to animals (COD) } \\
\text { World War II (COD) } \\
\text { World War II Pacific Front (MOH) }\end{array}$ & None observed \\
\hline $\begin{array}{l}\text { Historical Leader and } \\
\text { Hero }\end{array}$ & $\begin{array}{l}\text { Josef Stalin (COD) } \\
\text { Historical Vehicle }\end{array}$ & $\begin{array}{l}\text { Old weapons (COD, MOH, GTA, CS) } \\
\text { Radio, payphone (COD) }\end{array}$ \\
\hline
\end{tabular}

Table 4: Historical Factors in the Games

\section{Social Factors in Digital Games}

As shown in Table 5, social factors were emphasized in the games of both 2002-2004 and 2012-2014. In the games of 2002-2004, the importance of taking responsibility, being courageous, cooperating, devotion, acting as a group, and being a team were significant social factors. The 2012-2014 games featured unethical and immoral behaviors such as espionage, betrayal, harming others to win, and nakedness. In the WWII games, the interest of the soldiers in risque magazines stood out, and the soldiers also demonstrated social behaviors such as playing checkers and drinking wine. In football games, congratulating the players of losing teams was emphasized. Factors that created tension were also encountered, such as being aggressive while driving, planning robberies, speeding, taking drugs, using slang, and solving problems through violence. Finally, soldiers sending letters to family was also an important point in the games of 2002-2004. 


\begin{tabular}{|c|c|c|}
\hline Social Factors & 2002-2004 & 2012-2014 \\
\hline Cooperation & Cooperation and devotion (MOH) & $\begin{array}{l}\text { Appreciation (Crysis 3) } \\
\text { Cooperation and devotion (ACM, LOL, CODG) } \\
\text { Cooperation in the case of a disaster (DI) } \\
\text { Distinguishing mercy from weakness(LOL) } \\
\text { Guidance for the inexperienced (ACM) } \\
\text { Helping each other even in more difficult situations (TR) } \\
\text { Importance of motivation (ACM) }\end{array}$ \\
\hline $\begin{array}{l}\text { Ethical and } \\
\text { Moral Subjects }\end{array}$ & $\begin{array}{l}\text { Ambition to win (NFS) } \\
\text { Congratulating the opponent (FIFA) } \\
\text { Encouraging nakedness (GTA, } \\
\text { NFS) } \\
\text { Encouraging spying (GTA) } \\
\text { Magazines (MOH) }\end{array}$ & $\begin{array}{l}\text { Covering corpses (CODG) } \\
\text { Encouraging nakedness (GTA) } \\
\text { Encouraging spying (GTA) } \\
\text { The killing of defenseless animals (LOL) }\end{array}$ \\
\hline Family & $\begin{array}{l}\text { Soldiers sending letters to family } \\
\text { (COD) }\end{array}$ & $\begin{array}{l}\text { Childhood (MLL) } \\
\text { Fear of death (DI) } \\
\text { The grief of losing one's family (DI) }\end{array}$ \\
\hline $\begin{array}{l}\text { Social } \\
\text { Responsibility }\end{array}$ & $\begin{array}{l}\text { Courage of soldiers (COD) } \\
\text { Taking responsibility }(\mathrm{MOH})\end{array}$ & $\begin{array}{l}\text { Being modest in victory and virtuous in defeat (LOL) } \\
\text { Honesty (LOL) } \\
\text { Leaving children a world of nuclear disaster (MLL) } \\
\text { Opposition to nuclear weapons (MLL) } \\
\text { Importance of taking responsibility (CODG, LOL) } \\
\text { Prohibition against killing civilians (CODG) }\end{array}$ \\
\hline Social Tension & $\begin{array}{l}\text { Being aggressive while driving } \\
\text { (GTA, NFS) } \\
\text { Encouraging robbery (GTA) } \\
\text { Encouraging excessive speed (NFS) } \\
\text { Encouraging drug abuse (GTA) } \\
\text { Slang, swearing, and insulting Argo } \\
\text { (GTA) } \\
\text { Solving problems through violence } \\
\text { (GTA) }\end{array}$ & $\begin{array}{l}\text { Changing minds in difficult conditions (TR) } \\
\text { Encouraging bank robbery and theft (GTA) } \\
\text { Power of magic (LOL) } \\
\text { Power of technology (ACM, CODG, Crysis 3) } \\
\text { Solving problems through violence (GTA) } \\
\text { The impact of hunger on animal love (TR) }\end{array}$ \\
\hline Social Values & $\begin{array}{l}\text { Checkers (COD) } \\
\text { Vine (COD) }\end{array}$ & $\begin{array}{l}\text { Climbing as sport (TR) } \\
\text { Getting tattoos (GTA) } \\
\text { Healthcare (ACM) } \\
\text { Photographing extraordinary events (CODG) } \\
\text { Playing checkers, listening to music, playing the guitar } \\
\text { (MLL) } \\
\text { Soldiers' playing football (CODG) } \\
\text { Tennis, triathlon, parachute jumping, off-road race } \\
\text { (GTA) } \\
\text { Water sports (GTA) }\end{array}$ \\
\hline $\begin{array}{l}\text { Socialization } \\
\text { and } \\
\text { Togetherness }\end{array}$ & Being a team $(\mathrm{CS}, \mathrm{MOH})$ & $\begin{array}{l}\text { Being team (ACM, LOL, CODG) } \\
\text { Going to night clubs, having a girlfriend (GTA) } \\
\text { Making friends (LOL) }\end{array}$ \\
\hline
\end{tabular}

Table 5: Social Factors in Games

Table 5 also shows how the games frequently called for people cooperating with each other in the aftermath of profound nuclear disaster. Taking responsibility and demonstrating honesty, modesty, and virtue were heavily promoted, as well as cooperation, devotion, motivation, guidance, mercifulness, appreciation, and helping each other in difficult situations. Values that emphasize socialization, such as acting as a group, making friends, going to night clubs, and having a girlfriend, were included in the games, in addition to unethical and immoral factors such as killing animals, spying, and nakedness. Another interesting detail was the covering of corpses and occasional prohibition of killing civilians. In addition, sports activities such as tennis, triathlon, parachute jumping, off-road racing, water sports, swimming, and climbing had importance when social values were analyzed for the 2012-2014 games. Soldiers playing football, checkers, and guitar or listening to music, which are also linked to social 
values, were shown to happen even in difficult conditions. Other factors in the games of 2012-2014 were photographing extraordinary events, the importance of medical check ups, and getting tattoos. Last of all, family was also important in the games. The grief of losing family and the necessity of removing nuclear power to leave a beautiful world for children were major issues. On the other hand, incidents also occurred in which fear of death became more important than love of family. When tension-building social factors were analyzed, prevalent themes included magic, bank robbery and theft, the power of technological weapons, solving problems using violence, abandoning honesty in hard conditions, and the precedence of hunger over animal love.

\section{Presentation of Real-Life Scenarios in Digital Games}

As shown in Table 6, Medal of Honor: Pacific Assault and Call of Duty are about the Second World War. In GTA: Vice City, tasks take place in a realistic world of crime known as Vice City, which is based heavily on Miami, Florida. In Need for Speed: Underground, there is no specific plot, but car racing and speed are featured prominently. Counter Strike has no specific scenario, either; it focuses on clashes between two rival groups. FIFA only features football matches. The setting and components of all of these games were so well designed that they seemed almost real.

\begin{tabular}{|c|c|c|c|}
\hline & Name of the Game & $\begin{array}{l}\text { Suitability } \\
\text { for Real life }\end{array}$ & Summary of Scenarios \\
\hline \multirow{6}{*}{ 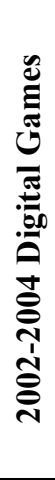 } & Call of Duty (COD) & 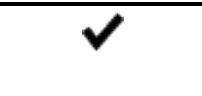 & $\begin{array}{l}\text { The scenario is World War II. Fighting is occurring on multiple } \\
\text { fronts, and relevant duties are carried out. }\end{array}$ \\
\hline & Counter Strike (CS) & 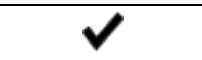 & There is no specific scenario. Two rival groups fight. \\
\hline & Fifa & 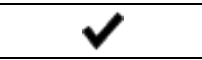 & There is no specific scenario. Football matches are played. \\
\hline & $\begin{array}{l}\text { Grand Theft Auto: Vice } \\
\text { City (GTA) }\end{array}$ & 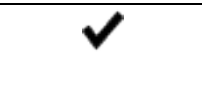 & $\begin{array}{l}\text { There is no specific scenario. Different missions are presented in } \\
\text { order to advance in the world of crime. }\end{array}$ \\
\hline & $\begin{array}{l}\text { Medal of Honor: } \\
\text { Pacific Assault (MOH) }\end{array}$ & & $\begin{array}{l}\text { The scenario is the World War II Pacific Front. Events were inspired } \\
\text { by the film Saving Private Ryan. }\end{array}$ \\
\hline & $\begin{array}{l}\text { Need For Speed } \\
\text { Underground (NFS) }\end{array}$ & & $\begin{array}{l}\text { There is no specific scenario. The focus is car racing and excessive } \\
\text { speed. }\end{array}$ \\
\hline \multirow{8}{*}{ 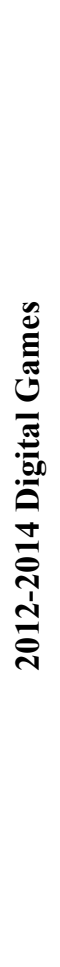 } & $\begin{array}{l}\text { Aliens: Colonial } \\
\text { Marines (ACM) }\end{array}$ & & $\begin{array}{l}\text { The scenario highlights the struggle of man against aliens after a } \\
\text { large scale space attack. }\end{array}$ \\
\hline & $\begin{array}{l}\text { Call of Duty: Ghost } \\
\text { (CODG) }\end{array}$ & & $\begin{array}{l}\text { A special organization called Ghost tries to save the world from the } \\
\text { Federation, which has taken control of a space craft called ODIN and } \\
\text { aims to be a super power. }\end{array}$ \\
\hline & Crysis 3 & & $\begin{array}{l}\text { By } 2047 \text {, the city of New York, which has been transformed into a } \\
\text { forest, has been captured by aliens. The main character, Prophet, } \\
\text { tries to save it and the rest of the planet from the CELL corporation. }\end{array}$ \\
\hline & Dead Island (DI) & & $\begin{array}{l}\text { Amid a horror theme, four survivors attempt to get rid of other } \\
\text { diseased vacationers on the island. }\end{array}$ \\
\hline & $\begin{array}{l}\text { Grant Theft Auto: } \\
\text { V(GTA) }\end{array}$ & & $\begin{array}{l}\text { There is no specific scenario. The game includes missions with such } \\
\text { tasks as robbery, and social events and illegal affairs are acutely } \\
\text { handled. It is possible to see different feelings about real life in the } \\
\text { game. }\end{array}$ \\
\hline & $\begin{array}{l}\text { League of Legends- } \\
\text { Online(LOL) }\end{array}$ & & $\begin{array}{l}\text { There is no specific scenario. An avatar called the champion, which } \\
\text { is inspired by mythological heroes, has different magical skills, and } \\
\text { two teams fight. }\end{array}$ \\
\hline & $\begin{array}{l}\text { Metro Last Light } \\
\text { (MLL) }\end{array}$ & & $\begin{array}{l}\text { This scenario features people taking shelter in a metro, trying to } \\
\text { survive after a nuclear disaster in Moscow. }\end{array}$ \\
\hline & Tomb Raider (TR) & & $\begin{array}{l}\text { Lara, a } 21 \text { year old female adventurer in search of ancient relics, is } \\
\text { caught in a storm on an island and struggles to rescue her friends } \\
\text { while facing the difficulties of life. }\end{array}$ \\
\hline
\end{tabular}

Table 6: Scenarios in Games 
Several games looked realistic but told unlikely stories. In Aliens: Colonial Marine, a game from 2012-2014, the aim is to rescue soldiers from alien creatures. Due to the nature of these creatures, much like the creatures in Crysis 3, this scenario could not truly happen. The situation is the same in Dead Island, where the goal is to evade and destroy diseased vacationers on the island. League of Legends, another game without a certain scenario, features the champion, which is inspired by mythological heroes and has a variety of skills. Upon choosing an avatar, a fight starts between the two teams by means of magic. Metro: Last Night is based on the difficult life children would face after nuclear disaster. Despite a fight against mutants, when generally considered, this game scenario could actually happen.

The scenarios of some the other analyzed 2012-2014 games were more similar to real life. In Call of Duty: Ghosts, technological weapons are heavily used in an effort to rid the world from secret organizations and gangs. This game makes predictions about the future and is similar to real life in terms of both technology and general worldview. In Grand Theft Auto V, a robbery theme comes to the forefront, and the game reflects many events from real life. Tomb Raider considers the beauty of nature and life, and an emphasis is placed on facing difficulties over time. Therefore, this game is representative of real life, as well.

\section{DISCUSSION AND CONCLUSION}

After analyzing these 14 digital games, many ideological, social, political, and historical factors became clear, as well as many changes and developments in game scenarios. Scenarios similar to real life are preferred in these games, and artificial intelligence is rarely used. In some games from 20022004, the importance of weapons and the power of the USA were heavily promoted, which may be because the games were of American origin. In some of the games, advertisements were encountered; therefore, it is possible to conclude that an aim was to direct players to these companies. In general, the games involved factors such as military discipline, obeying orders, and violating traffic rules. In Call of Duty, the soldier's necessity to spy is stressed, and a soldier has to be trained in Medal of Honor. The games make it clear how important discipline and training are for an American soldier. Whether the soldiers are winner or not is ignored in the games, though taking responsibility and being a team are important in Medal of Honor. In some of the games, World War II is depicted. Violence is opposed during football matches, but excessive speed and violating traffic rules are often encouraged. Socialization, helpfulness, family, and social values were not often seen, and religious elements were rarely mentioned in the analyzed games of 2002-2004. When the games were analyzed with regard to scenarios, the games of 2002-2004 either had no particular scenarios or their scenarios were fictionalized at a basic level. Fullerton (2008) stated in his study that digital game scenarios perform transitions from abstract to reality and from general to specific.

In the games of 2012-2014, ideological factors and themes were encountered such as the dangers of nuclear power, existence of aliens, bribery and corruption, founding secret organizations and gangs, and the USA rescuing the world from disasters. Similar factors often appear in modern media, particularly alongside violence (Erdoğan, Ekşi, \& Tektaş, 2012). In terms of social factors, cooperation was usually emphasized. Especially in online games, social values and environments are important. While in some games ethical and moral values were emphasized, fear and harmful factors were stressed in others. Although factors related to family were encountered, they were not at the forefront much. In the games of 2012-2014, political and historical factors were not heavily included, unlike social and ideological factors. This finding may stem from contemporary players not expecting many political and historical factors due to a lack of interest or knowledge. In addition, game companies may have avoided political arguments to ensure universal characteristics and increased likelihood of global popularity.

Most of the scenarios in the 2012-2014games depended heavily on future predictions. The games reflected real life well, and artificial intelligence, nature, modern architecture and advanced technology were meticulously transferred to the setting. Studies conducted in social fields have shown how public interest in holy factors has increased recently; at the same time, magical powers, mystical or spiritual factors, and fantastic concepts have increased in popular culture as well (Arslan, 2010; 
Bell, 2006). Arslan (2010) has observed religious, mystical, and fantastic themes emerging in television programs, films, and literature. This situation has also been observed in digital games. Aliens: Colonial Marines, Crysis 3, Dead Island, League of Legends, and Metro: Last Light in particular do not have realistic scenarios, and the use of factors such as magic, aliens, creatures, and mutants provide further evidence of this growing tendency.

For Call of Duty, both the 2002-2004 and 2012-2014 versions were analyzed. The Second World War was the theme in 2002-2004, while the 2012-2014 game mainly focuses on fighting against spaceoriented armed forces that might appear in the future, once again demonstrating the tendency to present unrealistic factors. The game incorporated a historical scenario in 2002-2004, but in 20122014 , it used a scenario completely based on modernism, technology, and future predictions. The storyline of the 2002-2004 game is a simple linear process, while the 2012-2014 version presents a more open environment in which artificial intelligence reacts to even small details amid a broad scope. Technological developments have clearly made an impact on game content.

Generally, cooperation and teamwork played significant roles in all analyzed games. Grand Theft Auto $\mathrm{V}$, which reasonably reflects some aspects of social life, emphasizes the importance of social values as well as factors that encourage negative behavior in terms of ethical and moral values, such as bribery, corruption, car theft, nakedness, and robbery. Garite (2003) mentioned in his study that the driver in GTA aims to steal cars without mentioning it is a crime. Also, there is an implication that nothing should stand in one's way of success in the races in Need For Speed, although careful driving is stressed in the game as well. Meanwhile, FIFA 2003 can be defined as a idealized game in terms of football; it is certainly not common in real life for a footballer to apologize after a foul. The increasing ovations coming from the audience show that violence is not acceptable. Despite an absence of ideological factors in Counter Strike, a finding confirmed by Sicart (2003), the use of weapons of that period during terrorist clashes stands out, and it cannot be disregarded how one player in the game takes on the role of terrorist. In this game, both team play and individual skills are stressed.

Although the easy destruction of creatures with extraordinary power seems contradictory compared with real life, Aliens: Colonial Marines emphasizes the fact that no living things can cope with human beings and with the weapons they have invented. Thus, this game gives great importance to human power. The most conspicuous factor in League of Legends is the handling of the theme of fear of death, and the element of reincarnation could be evaluated as a religious factor. In addition, the perception that justice will not always be served but may be obtained through factors such as power or magic is stressed in the game. The similar prevalence of vigilante justice in films and television series can be attributed to a lack of confidence in the justice system, which is highly emphasized in the media.

In Call of Duty: Ghosts, young people are shown taking pictures of explosions and devastation with their mobile phones. The media frequently points to the irony of people recognizing terrible situations but choosing to take pictures rather than moving to help. Interestingly, when the main character Logan dies or a player logs off during a fight, the warning "You have left your friends alone" appears on the screen, stressing the aspect of responsibility to others. From a general perspective, the events in Metro: Last Light could be considered very realistic: biological and nuclear wars waged by humans could easily affect the world to a great extent, even ending life on earth. In Tomb Raider, the fear of death and struggle to survive changes people's thoughts, and the precedence of hunger over love for animals is also important.

Historical factors definitely decreased in use in the analyzed games. Sisler (2005) has claimed that digital games of the 1990s were used in efforts to transfer certain ideologies to players by some groups. Some historical events highlight the power of specific countries, while the efficiency of other countries is shown as weakened. This tendency in games has almost completely disappeared. Fantastic themes and social values have emerged in the games alongside the use of artificial intelligence. Increased factors such as social responsibility and resistance against nuclear weapons indicate a modern general worldview. Based on these analyzed factors, digital games are becoming more similar 
to real life, and the events that are being transferred into the games often maintain significant excitement. Further, strong tendencies for featuring future predictions, likely world events, and the roles of possible super powers have developed in modern digital games.

\section{REFERENCES}

Arslan, M. (2010). Holy searches in secular communities: Sociological analysis of magic-religion relationship in the late modern period. Journal of the Inonu University Faculty of Theology, 1(1), 195210.

Bat1, U. (2011). Superordinate reality, identity and usual violence. Retrieved from http://www.ugurbati.com/Portals/0/makaleler/A47_D\%C4\%B0jital_Oyunlar_K\%C3\%BClt\%C3\%BCr .pdf

Bell, D. (2006). The return of the holy: Secular but holy. (A. Köse, Trans.). Istanbul, Turkey: Etkileşim Publications.

Binark, M., \& Bayraktutan-Sütçü, G. (2009). Playing the Turkishness in the great online games: Building the congregation in online Silk Road and its Turkish characteristics. In M. Binark, G. Bayraktutan-Sütçü, \& I. B. Fidaner (Eds.), Guide of Digital Games. Istanbul, Turkey: Kalkedon Publications.

Boyle, E. A., Connolly, T. M., \& Hainey, T. (2011). The role of psychology in understanding the impact of computer games. Entertainment Computing, 2(2), 69-74.

Brisbois, K. (Producer). (2007). The history of the video game [Television broadcast]. Hollywood, CA: World of Wonder.

Çepni, S. (2007). Introduction to research and project studies. Trabzon, Turkey: Pegem Akademi Publications.

Demir, N. K. (2005). A research on the legitimation the family ideology in the TV commercials. Ege University New Thoughts Journal, 1(1), 153-173.

Dondlinger, J. M. (2007). Educational video game design: A review of the literature. Journal of Applied Educational Technology, 4(1), 21-31.

Elverdam, C., and\& Aarseth, E. (2007). Game classification and game design: Construction through critical analysis. Games and Culture, 2(1):, 3-22.

Erdoğan, Y., Ekşi, H., \& Tektaş, A. (2012). Medya ve şiddet: Mafya dizileri üzerine karma bir araştırma [English translation]. Değerler Ĕ̌itimi Dergisi [English translation], 10(23), 83116.Fullerton, T. (2008). Documentary games: Putting the player in the path of history. In Z. Whalen \& L. Taylor (Eds.), Playing the past: Nostalgia in video games and electronic literature. Nashville, TN: Vanderbilt University Press.

Galloway, A. R. (2004). Social realism in gaming. The International Journal of Computer Game Research, 4(1). Available at http://www.gamestudies.org/0401/galloway/

Garite, M. (2003). The ideology of interactivity (or, video games and the taylorization of leisure). In Proceedings of 2003 DIGRA International Conference: Level Up.

Grifitts, M. (2010). Online video gaming: What should educational psychologists know? Educational Psychology in Practice, 26(1), 35-40.

Güriz, A. (1995). A research on capitalist ideology. Ankara, Turkey: Siyasal Bookshop.

Huizinga, J. (1995). Homo ludens: An article on the social function of the games. (M. A. Kilıçbay, Trans.). İstanbul, Turkey: Ayrıntı Publications.

Kan, D. (2012). Yeni Medya Aracı Bilgisayar Oyunlarında Toplumsal Cinsiyetin İnşası. The Turkish Online Journal of Design Art and Communication, 2(4), 52-60.

Malliet, S., Thysen, T., \& Poels, P. (2011). Digital game rhetoric and critical reasoning: The case of Grand Theft Auto IV and America's Army: Special Forces. In K. Poels \& S. Malliet (Eds.), Vice City Virtue: Moral Issues in Digital Game Play (pp. 245-264). Leuven, Belgium: Acco Academic.

Mardin, Ş. (2007). Religion and ideology. İstanbul, Turkey: İletişim Publications.

Oktay, C. (2009). And they define such a measure as politics. Notes on the Definition of politics by Tursun Bey. Istanbul University Faculty of Political Science Journal, 40(4), 43-51.

Rutter, J., \& Bryce, J. (2006). Understanding digital games. London, England: Sage.

Sayllgan, Ö. B. (2012). The ideology of interactivity: Digital games. Retrieved from http://dijitaloyun.wordpress.com/2012/12/19/2347/ 
Sicart, M. (2003). Family values: Ideology, computer games \& The Sims. In Proceedings of 2003 DIGRA International Conference: Level Up.

Şimşek, A. (2011). Searching science to object of past as archeology: The situation in history teaching in Turkey. Turkish Studies-International Periodical for the Languages, Literature and History of Turkish or Turkic, 6(2), 919-934.

Sisler, V. (2005). Videogames and politics. In EnterMultimediale 2, International Festival of Art and New Technologies, Praha: CIANT: 38-40.

Squire, K. (2006). Games as ideological worlds. Retrieved from http://www.academiccolab.org/resources/documents/edreacher-submitted.pdf

Squire, K., \& Jenkins, H. (2003). Harnessing the power of games in education. Insight, 3(1), 5-33.

Sucu, İ. (2012). Shifting of the reality fact in social media games: The sample game Smeet. Gümüshane University Electronic Journal of Communication Faculty, 3(3), 55-88. Warnes, C. (2005). Baldur's Gate and history: Race and alignment in digital role playing games. In Proceedings fo the 2005 DIGRA International Conference: Changing View: Worlds in Play..

Yıldırım, A., \& Şimşek, H. (2011). The qualitative research methods of social sciences. Ankara, Turkey: Seckin Publication. 